\title{
CARDIOVASCULAR CHANGE IN ATHLETES AT DIFFERENT TRAINING STATUS LEVELS
}

\author{
MUDANÇA CARDIOVASCULAREM ATLETAS EM DIFERENTES NIVEIS DE TREINAMENTO \\ CAMBIOS CARDIOVASCULARES EN ATLETAS CON DIFERENTES NIVELES DE ENTRENAMIENTO
}

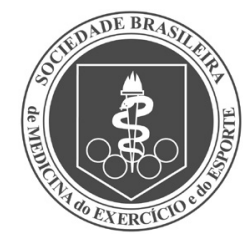

Original Article Artigo Original Artículo Original
Xiumei Zhang ${ }^{1}$ (ID

(Physical Education Professional)

1. Shanghai Publishing and Printing College, Basic Teaching Department, Shanghai, China.

Correspondence: Xiumei Zhang. Shanghai, 200093, China. XiumeiZhang2@126.com

\begin{abstract}
Introduction: Heart rate and blood pressure are important physiological indicators that reflect cardiovascular function, and they are widely used because they are convenient and practical to measure. Objective: To study the characteristics of cardiovascular changes in athletes under different training conditions. Methods: Thirty-four male students majoring in physical education in universities (group A) and 22 male non-sports majors (group B) with no formal training history were randomly selected. Heart rate before and after exercise and heart rate recovery rate at different stages of the recovery period were compared. Results: As regards heart rate changes in the recovery phase after loading, both groups showed a continuous decline, although the drop in heart rate of group A was slightly lower than that of group B (153.03 \pm 15.88 beats/min, dropped to $110.69 \pm 15.78$ beats/ minute, $171.00 \pm 14.67$ beats/minute dropped to $122.82 \pm 13.77$ beats/min, respectively). However, the heart rate recovery rate of group A (59.40\%) was significantly higher than that of group B $(49.42 \%)(P<0.05)$. Conclusions: Physical exercise plays a significant role in promoting physical fitness and its effect on improving cardiovascular function is especially evident. Level of evidence Il; Therapeutic studies - investigation of treatment results.
\end{abstract}

Keywords: Cardiovascular; Heart rate; Exercise.

\section{RESUMO}

Introdução: A frequência cardíaca e a pressão arterial são indicadores fisiológicos importantes que refletem a função cardiovascular e são amplamente usados porque são convenientes e práticos de medir. Objetivo: Estudar as características das alterações cardiovasculares em atletas em diferentes condições de treinamento. Métodos: Trinta e quatro estudantes do sexo masculino com especialização universitária em educação física (grupo A) e 22 estudantes do sexo masculino não esportistas (grupo B) sem histórico de treinamento formal foram randomicamente selecionados. A frequência cardíaca antes e depois do exercício e a taxa de recuperação da FC em diferentes estágios do período de recuperação foram comparadas. Resultados: Com relação às mudanças da frequência cardíaca na fase de recuperação após carga, ambos os grupos mostraram declínio contínuo, embora a queda da frequência cardíaca do grupo A tenha sido ligeiramente menor do que a do grupo B (153,03 $\pm 15,88$ bpm, caiu para 110,69 \pm 15,78 bpm, 171,00 $\pm 14,67$ bpm caiu para 122,82 $\pm 13,77$ bpm, respectivamente). Contudo, a taxa de recuperação da frequência cardiaca do grupo A $(59,40 \%)$ foi significativamente maior do que a do grupo $B(49,42 \%)(P<0,05)$. Conclusões: O exercício físico tem um papel significativo na promoção da aptidão física e seu efeito na melhora da função cardiovascular é especialmente evidente. Nível de Evidência ll; Estudos terapêuticos - Investigação dos resultados do tratamento.

Descritores: Cardiovascular; Frequência cardíaca; Exercício.

\section{RESUMEN}

Introducción: La frecuencia cardíaca y la presión arterial son importantes indicadores fisiológicos que reflejan la función cardiovasculary se utilizan ampliamente porque son convenientes y prácticos de medir. Objetivo: Estudiar las características de los cambios cardiovasculares en atletas bajo diferentes condiciones de entrenamiento. Métodos: Se seleccionaron aleatoriamente 34 estudiantes del sexo masculino con una especialización universitaria en educación física (grupo A) y 22 estudiantes del sexo masculino no deportistas (grupo B) sin antecedentes de entrenamiento formal. Se comparó la frecuencia cardíaca antes y después del ejercicio y la tasa de recuperación de la FC en diferentes etapas del período de recuperación. Resultados: En cuanto a los cambios en la frecuencia cardiaca en la fase de recuperación tras la carga, ambos grupos presentaron un descenso continuo, aunque la caída de la frecuencia cardíaca del grupo

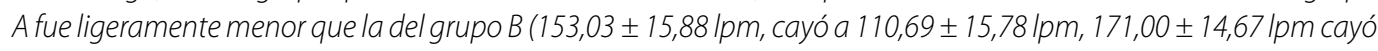
a 122,82 $\pm 13,77 \mathrm{lpm}$, respectivamente). Sin embargo, la tas a de recuperación de la frecuencia cardíaca del grupo A $(59,40 \%)$ fue significativamente mayor que la del grupo $B(49,42 \%)(P<0,05)$. Conclusiones: El ejercicio físico tiene un papel importante en la promoción de la aptitud física y su efecto en la mejora de la función cardiovascular es especialmente evidente. Nivel de Evidencia ll; Estudios terapéuticos - Investigación de los resultados del tratamiento.

Descriptores: Cardiovascular; Frecuencia cardíaca; Ejercicio. 


\section{INTRODUCTION}

Improving heart function is one of the main training goals of many sports events (especially endurance events). 'Therefore, grasp the characteristics of the adaptability changes of the athlete's heart function to long-term training and the stress changes caused by different loads, for sports selection, evaluate the training effect, improving training methods has very important theoretical and practical significance. ${ }^{2}$ The cardiovascular response caused by exercise is very complicated. During exercise, due to changes in the excitability of the autonomic nervous system, changes in the factors, etc., the blood flow throughout the body will be redistributed. ${ }^{3}$ Specifically for heart function, the load before and after the heart contract changes, arterial elasticity, the caliber of the blood vessel will change, the peripheral resistance will change, the rate of myocardial contraction changes, the initial length of myocardial fibers changes before contraction, the recovery blood volume will change, heart rate and SV (stroke volume), CO (output per minute) will change, and blood pressure and blood flow speed will also change accordingly. ${ }^{4}$ Aslani $P$ and others believe that the highest level of competition depends on genetic and environmental influences, only properly train during the critical period of individual development and growth, its potential ability can be fully utilized. ${ }^{5}$

\section{METHOD}

\section{Research objects}

A random selection of 34 males majoring in physical education in colleges (group A) will take part in formal training for 2-10 years. 22 non-sports major boys (group B), no formal training history. All subjects are in good health, see Table 1 for the basic conditions of no cardiovascular system diseases.

\section{Research methods}

After the subjects sat quietly for 10 minutes, the heart rate and blood pressure were measured in a relatively quiet state. After that, the J-205 type constant power vehicle is used to perform three-level incremental load (power respectively 150W, 180W and 225W, namely load 1, 2, 3), each pedaling time is 3 minutes, the speed is $60 \mathrm{rpm}$. Measure heart rate and blood pressure for 10 seconds immediately after all levels of load, immediately after the end of the measurement, the next level of load exercise was performed. After the level 3 load is completed, the subject sits on the power car, the heart rate and blood pressure were measured for 10 seconds at 15 seconds, 40 seconds, 65 seconds, and 2 minutes in the recovery phase (ie, recovery $1,2,3$, and 4 ). With a relatively quiet heart rate as the base, calculate the heart rate growth rate (\%) after all levels of load. Taking the difference between the heart rate after maximum load and the relative resting heart rate as the base, calculate the heart rate recovery rate (\%) at different stages of the recovery period. After statistical processing, compare and analyze the measured indicators of $A$ and $B$ groups. ${ }^{6}$

Table 1. A, B, general situation of the two groups of students.

\begin{tabular}{c|c|c|c}
\hline Group & Age & Height & Weight \\
\hline Group A & $21.82 \pm 0.79$ & $176.88 \pm 4.42$ & $70.03 \pm 5.46$ \\
\hline Group B & $21.68 \pm 0.72$ & $172.18 \pm 5.04$ & $85.46 \pm 5.93$ \\
\hline
\end{tabular}

\section{RESULTS}

\section{Heart rate}

After testing, regardless of the quiet state, it's the load increase stage at all levels and the recovery stage, the heart rates of the students in group A were significantly lower than those in group $B(P<0.01)$, as shown in Table 2. Heart rate changes after load, although the two groups A and $B$ are accelerating at the same time, however, the increase rate of group
Table 2. Comparison of heart rate between the two groups A and B in different periods.

\begin{tabular}{c|c|c|c}
\hline Group & Group A & Group B & t \\
\hline Quiet & $66.56 \pm 5.42$ & $76.54 \pm 8.65$ & 5.0001 \\
\hline Load 1 & $110.53 \pm 10.31$ & $123.27 \pm 13.57$ & 3.1976 \\
\hline Load 2 & $132.29 \pm 12.39$ & $115.64 \pm 14.48$ & 3.6845 \\
\hline Load 3 & $153.03 \pm 15.88$ & $171.00 \pm 14.67$ & 4.2194 \\
\hline Restore 1 & $136.44 \pm 16.75$ & $152.73 \pm 15.13$ & 3.6889 \\
\hline Restore 2 & $125.29 \pm 17.21$ & $140.73 \pm 15.71$ & 3.3138 \\
\hline Restore 3 & $115.35 \pm 16.77$ & $131.91 \pm 15.05$ & 3.5271 \\
\hline Restore 4 & $110.69 \pm 15.78$ & $122.82 \pm 13.77$ & 3.1927 \\
\hline
\end{tabular}

A is lower than that of group $B$ at all levels of load, the heart rate growth rate of group $A$ was significantly higher than that of group $B(P<0.05$, $P<0.01$ ), as shown in Table 3. It shows that the heart rate acceleration value and the rate growth rate are not synchronized. 'Heart rate changes in the recovery phase after loading, both groups showed a continuous decline, although the heart rate drop in group A is slightly lower than that in group B (Reduced from 153.0315.88 times/min, 171.0014.67 times/ min to 110.6915 .78 times/min, 122.8213 .77 times/min), however, the heart rate recovery rate of group A (59.40\%) was significantly higher than that of group $B(49.42 \%)(P<0.05)$. This result also shows the asynchrony between the heart rate drop and the heart rate recovery rate. The above results suggest: When using heart rate changes to evaluate cardiovascular function, attention should be paid to avoiding one-sided observation of heart rate changes and neglecting the influence of resting heart rate. ${ }^{8}$

\section{Blood pressure}

The systolic blood pressure of the A.B group was slightly higher when the group $A$ was at rest, but the difference is not significant $(P>0.05)$. As the load increases during exercise, the systolic blood pressure of the two groups increased in different trends. Group A had a smaller response to increasing load, it shows that the rise value is slightly larger when the load is level 1 (power 150W), at the second and third levels of load (power 180W, 225W), there was a small continuous increase. The increase in group $B$ is greater when the load is level 1.2, the rising value was significantly higher than that of group $A(P<0.05)$, however, myocardial contraction is weak at the third level of load, and there is a drop in systolic blood pressure, the comparison of systolic blood pressure values between groups $A$ and $B$ during different periods is shown in Figure 1. This shows that physical education students have a strong adaptability to the increase in load and a strong myocardial contraction function when the maximum load is completed. In the recovery period, the changes of systolic blood pressure in the two groups were similar $(P>0.05)$, and the decline in group A was slightly higher than that in group B.

\section{DISCUSSION}

Heart rate is one of the most commonly used physiological indicators in cardiac activity. It can be used to measure the strength of an individual's cardiovascular function. ${ }^{9}$ The increase in heart rate during exercise is an adaptive response to exercise, but when the sub-polarity is most active, the increase in heart rate is not only related to exercise intensity and duration, and it is related to the physical fitness level of the athlete, training level related, similarly, the heart rate recovery speed after exercise is also an evaluation index of function and training level, the time for heart rate recovery after exercise is shorter for those with training than those without training. ${ }^{10}$ Therefore, the growth rate of the exercise center rate and the recovery speed of the heart rate after exercise are widely used to assess the body's cardiovascular function level. The heart rate growth rate under load and the heart rate recovery rate in the recovery phase have excluded the interference of low heart rate values in the quiet state, therefore, a single absolute heart rate 
Table 3. Comparison of heart rate growth rate and recovery rate between groups A and B in different periods.

\begin{tabular}{|c|c|c|c|c|c|c|c|}
\hline Group & Load 1 & Load 2 & Load 3 & Restore 1 & Restore 2 & Restore 3 & Restore 4 \\
\hline Group A & $67.35 \pm 10.59$ & $100.24 \pm 14.19$ & $137.12 \pm 17.64$ & $22.95 \pm 8.52$ & $36.25 \pm 11.68$ & $47.00 \pm 10.07$ & $56.40 \pm 10.55$ \\
\hline Group B & $61.45 \pm 13.39$ & $91.41 \pm 20.57$ & $124.91 \pm 13.21$ & $19.07 \pm 10.16$ & $30.93 \pm 11.98$ & $40.52 \pm 12.71$ & $49.42 \pm 13.32$ \\
\hline $\mathrm{t}$ & 1.8338 & 1.9029 & 2.7781 & 1.7408 & 1.8071 & 1.8823 & 1.9349 \\
\hline
\end{tabular}

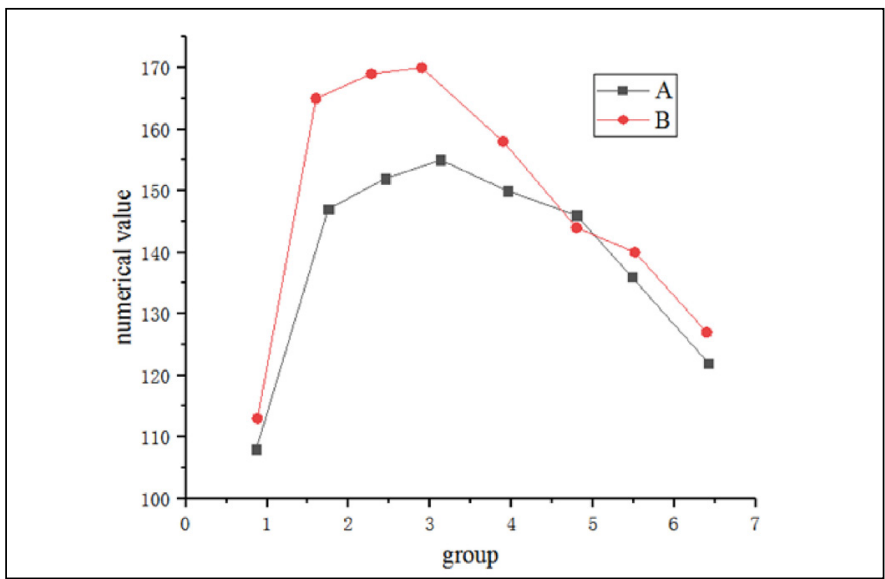

Figure 1. Comparison of systolic blood pressure values between groups $A$ and $B$ in different periods.

increase or decrease value can objectively reflect the cardiovascular function during exercise. A lot of research proves: Exercise training can reduce the heart rate at rest and under a fixed load, speed up the heart rate recovery after exercise, the recovery period is shortened, the fast growth of the sports center rate is the fast mobilization of functions, powerful performance, a high recovery rate also indicates a high level of cardiovascular function." In this experiment, the longitudinal observation of the change of the exercise center rate and the growth rate of the heart rate under load, lateral study of recovery rate after load, especially from within the same time, under the same load, physical education students are in a quiet state, load exercise, still, the heart rate during the recovery period after exercise is lower than that of the non-sports professional group, the heart rate growth rate and recovery rate are significantly higher than those of the non-sports professional group, it shows that physical education students have less energy consumption in the cardiovascular system when they are quiet, features of function saving, as well as having a greater heart rate reserve and functional potential under load, this is a reflection of good heart function and physical fitness, at the same time, it shows that exercise training can improve the adaptability of heart function. The increase in muscle oxygen consumption during exercise will lead to a series of regulatory changes in the cardiovascular system, especially manifested as changes in arterial blood pressure.

\section{CONCLUSION}

Physical education students have less energy consumption in the cardiovascular system when they are quiet, features of function saving, as well as having a greater heart rate reserve and functional potential under load, this is a reflection of good heart function and physical fitness, at the same time, it shows that exercise training can improve the adaptability of heart function.

The author declare no potential conflict of interest related to this article

AUTHORS' CONTRIBUTIONS: The author made significant contributions to this manuscript. Xiumei Zhang: writing and performing surgeries; data analysis and performing surgeries; article review and intellectual concept of the article.

\section{REFERENCES}

1. Gao Z, Li B, Li J,Zhang Y, Ren C, Wang B. Study on the Adsorption and Thermodynamic Characteristics of Methane under High Temperature and Pressure. Energy Fuels. 2020;34(12):15878-93.

2. Faghihzadeh F, Adibi P, Hekmatdoost A. The effects of resveratrol supplementation on cardiovascular risk factors in patients with non-alcoholic fatty liver disease: a randomised, double-blind, placebo-controlled study. Br J Nutr. 2015;114(05):796-803.

3. Puspitasari HP, Aslani P, Krass I.The influence of pharmacy and pharmacist characteristics on the secondary prevention of cardiovascular disease. Int J Clin Pharm. 2015;37(5):834-43.

4. Rheault MN, Molony JT, Nevins T, Herzog CA, Chavers BM. Hemoglobin of $12 \mathrm{~g} / \mathrm{dl}$ and above is not associated with increased cardiovascular morbidity in children on hemodialysis. Kidney Int. 2017;91(1):177-82.

5. Eikendal A, Bots ML, Aisha G, Lutgens E, Hoefer IE, Rujiter HM den, et al. Circulating levels of P-selectin and E-selectin relate to cardiovascular magnetic resonance-derived aortic characteristics in young adults from the general population, a cross-sectional study. J Cardiovasc Magn Reson. 2018;20(1):54.
6. DWang, Ma N, Cheng G. Study on the Characteristics of Electromechanical Disturbance Propagation in Non-Uniform Power Systems. IET Gener Transm. 2017;11(8):1919-25.

7. Triki F, Jdidi J, Abid D, Tabbabi N, Charfeddine S, Kahla SB, et al. Characteristics, aetiological spectrum and management of valvular heart disease in a Tunisian cardiovascular centre. Arch Cardiovasc Dis. 2017;110( 8-9):439-46.

8. Yang S, Wang Q, Shi W, Guo W, Jiang Z, Gong X. Numerical study of biomechanical characteristics of plaque rupture at stenosed carotid bifurcation: a stenosis mechanical property-specific guide for blood pressure control in daily activities. Acta Mechanica Sinica. 2019;35(6):1279-89.

9. Roberta DR, Mariuca VN, Leistner DM, Reis SM, Thome CE, Boeckel JN, et al. Coronary Atherosclerotic Plaque Characteristics and Cardiovascular Risk Factors - Insights From an Optical Coherence Tomography Study. Circulation Journal. 2017;81(8):1165-73.

10. Lethielleux G, Amar L, Raynaud A, Plouin PF, Steichen O. Influence of Diagnostic Criteria on the Interpretation of Adrenal Vein. Hypertension. 2015;65(4):849-54. 